\title{
A study of structural lineaments in Pantanal (Brazil) using remote sensing data
}

\author{
ANTONIO C. PARANHOS FILHO ${ }^{1,2^{*}}$, ALEXIS R. NUMMER ${ }^{2,3^{* *}}$, \\ EDILCE A. ALBREZ ${ }^{1}$, ALISSON A. RIBEIRO ${ }^{1}$ and RÔMULO MACHADO ${ }^{2}$ \\ ${ }^{1}$ Centro de Ciências Exatas e Tecnologia, Universidade Federal de Mato Grosso do Sul, \\ Campus Universitário, s/no ${ }^{\circ}$ Caixa Postal 549, 79070-900 Campo Grande, MS, Brasil \\ ${ }^{2}$ Instituto de Geociências, Universidade de São Paulo, Rua do Lago, 562, 05508-080 São Paulo, SP, Brasil \\ ${ }^{3}$ Departamento de Geociências, Instituto de Agronomia, \\ Universidade Federal Rural do Rio de Janeiro, Rod. BR 465, Km 7, 23890-000 Seropédica, RJ, Brasil
}

Manuscript received on April 24, 2012; accepted for publication on February 27, 2013

\begin{abstract}
This paper presents a study of the structural lineaments of the Pantanal extracted visually from satellite images (CBERS-2B satellite, Wide Field Imager sensor, a free image available in INTERNET) and a comparison with the structural lineaments of Precambrian and Paleozoic rocks surrounding the Cenozoic Pantanal Basin. Using a free software for satellite image analysis, the photointerpretation showed that the NS, NE and NW directions observed on the Pantanal satellite images are the same recorded in the older rocks surrounding the basin, suggesting reactivation of these basement structural directions during the Quaternary. So the Pantanal Basin has an active tectonics and its evolution seems to be linked to changes that occurred during the Andean subduction.
\end{abstract}

Key words: free remote sensing software, free satellite images, structural geology, lineaments, photointerpretation, Pantanal.

\section{INTRODUCTION}

The main purpose of this paper is to study the structural lineaments of the Pantanal extracted from CBERS-2B satellite images (Wide Field Imager sensor - WFI) combined with field information, and to investigate possible relationships between the structural directions thus obtained and the reactivation of the basement structures.

Besides the identification of geological structures, another purpose of this study is the utilization of free satellite images and a free software in order to evaluate their potential as structural analysis tools.

Correspondence to: Alisson André Ribeiro

E-mail: geotec.ribeiro@gmail.com

*Bolsista CNPq

**Estagiário de Pós-Doutorado
In the present work we identified three main lineament directions: NE, around N-S, and E-W. The first two structures are older and related to reactivations of basement structures. The youngest E-W developed from the end of the Cenozoic to the Quaternary.

In this paper the term lineament is used according to the definition of O'Leary et al. (1976), "mappable linear surface features which differ distinctly from the patterns of adjacent features and presumably reflect subsurface phenomena".

The study area encompasses not only the Pantanal but also the surrounding Precambrian rocks and the northwestern margin of the Phanerozoic Paraná Basin. 
Pantanal is a plain humid area situated in the middle of the South America Plate. Due to its biodiversity, which is one of the largest in the world, it is considered part of the human patrimony. The origin of the Pantanal Basin is still not well understood and if on one hand it is possible to attest a tectonic origin for the Pantanal basin, on the other hand, the main structural systems have not been made available in the scientific literature. Thus, the aim of this work is to present the main Pantanal structural systems compiled from photointerpretation of remote sensing images checked against field data.

GEOLOGICAL SETTING

In his pioneer work on the Brazilian and South American tectonics, Almeida (1967) describes two regions that were the sites of sedimentation on the South American Platform during the Quaternary: the Amazon and the Pantanal basins.

The Pantanal is nowadays a region of intense sedimentation, even in human terms (Ab'Saber 1988, 2006). Despite the alleged stability during the Cenozoic, the Pantanal Basin shows several evidences of recent and current tectonic activities (Assine 2010, Assine and Soares 2004, Hasui 1990, 2010, Assumpção and Suárez 1988, Assumpção et al. 2009a, b, Facincani et al. 2011, Zani and Assine 2011).

Riccomini and Assumpção (1999) explain that the concept of tectonic stability has long prevailed for most of the South American Platform. Therefore, the investigation on the Quaternary tectonics in Brazil has begun only in the 1990's.

Assine (2010) considers the Pantanal as a tectonically active sedimentary basin, with many of its morphological features resultant from a paleogeographic evolution conditioned by climatic and tectonic changes that have occurred since the late Pleistocene to the present day. The author points out to the presence of active faults within the Pantanal Basin and considers that many of them are related to the Transbrasiliano lineament.
Pantanal has been considered a seismic region at least since the beginning of the twentieth century (Branner 1912). Even being inside the South American plate neotectonic activities have been documented, even including several earthquakes records (Assumpção et al. 2009a, Facincani et al. 2011).

Zani and Assine (2011) present the results of the systematic mapping of the Taquari River megafan paleochannels using remote sensing images and conclude that there are areas under the influence of recent tectonic movements.

Ruellan (1952, apud Ab'Saber 1988) is the first to identify the physiographic feature containing the Pantanal depression and called it an inlier: a geomorphological term used to describe an inversion of the relief. It is represented by a wide arcuate shield (called "aboboda") formed by Precambrian terrains excavated by erosional processes, which in this case ended up forming the depression occupied by Pantanal Basin.

The relief of this region originated in the late Cretaceous, when there was no Paraguay depression. Instead, there was an elevated region between the Andean region and the northwestern portion of the Paraná sedimentary basin (Almeida 1965). In the region that nowadays corresponds to the Upper Paraguay hydrographic basin major faulting took place, affecting the Precambrian rocks. The Upper Paraguay hydrographic basin contains the Pantanal Plain and its former rivers.

Almeida (1965) identifies a set of NNE-SSW structures affecting the Gran Chaco in Bolivia and Paraguay and the main core of the Brazilian Upper Paraguay river basin, representing two separated tectonic compartments, limited by the hills along the border between Brazil and Bolivia. So the Post-Cretaceous and Pre-Pliocene tectonics may have been wider and more complex than the residual tectonics that has been responsible for the generation of the Pleistocenic Pantanal Basin.

According to Ab'Saber (1988, 2006), the Pantanal formed in the Pleistocene was the result 
of a regional system of faults forming a graben system inside the boutinière.

The regional context is represented in Figure 1 (Companhia de Pesquisa de Recursos Minerais (CPRM) - Schobbenhausa and Bellizzia 2001). It is possible to observe the main structures around the Pantanal Basin, as follows:

- the Paraguay belt to the north, with Precambrian metamorphic structures following a NNE/SSW trend;
- the EW/EEW-trending Proterozoic rocks of the Tucavaca belt to the west, surrounded by Quaternary/ Cenozoic sediments from Bolivia and several hills aligned NNE/SSW on the Brazil - Bolivia border;

- the NS-trending Bodoquena Hills to the south constituted by Precambrian carbonates and highgrade metamorphic rocks;

- the Pantanal eastern border with the Paraná Sedimentary Basin, constituted by an almost NStrending tectonic structure.
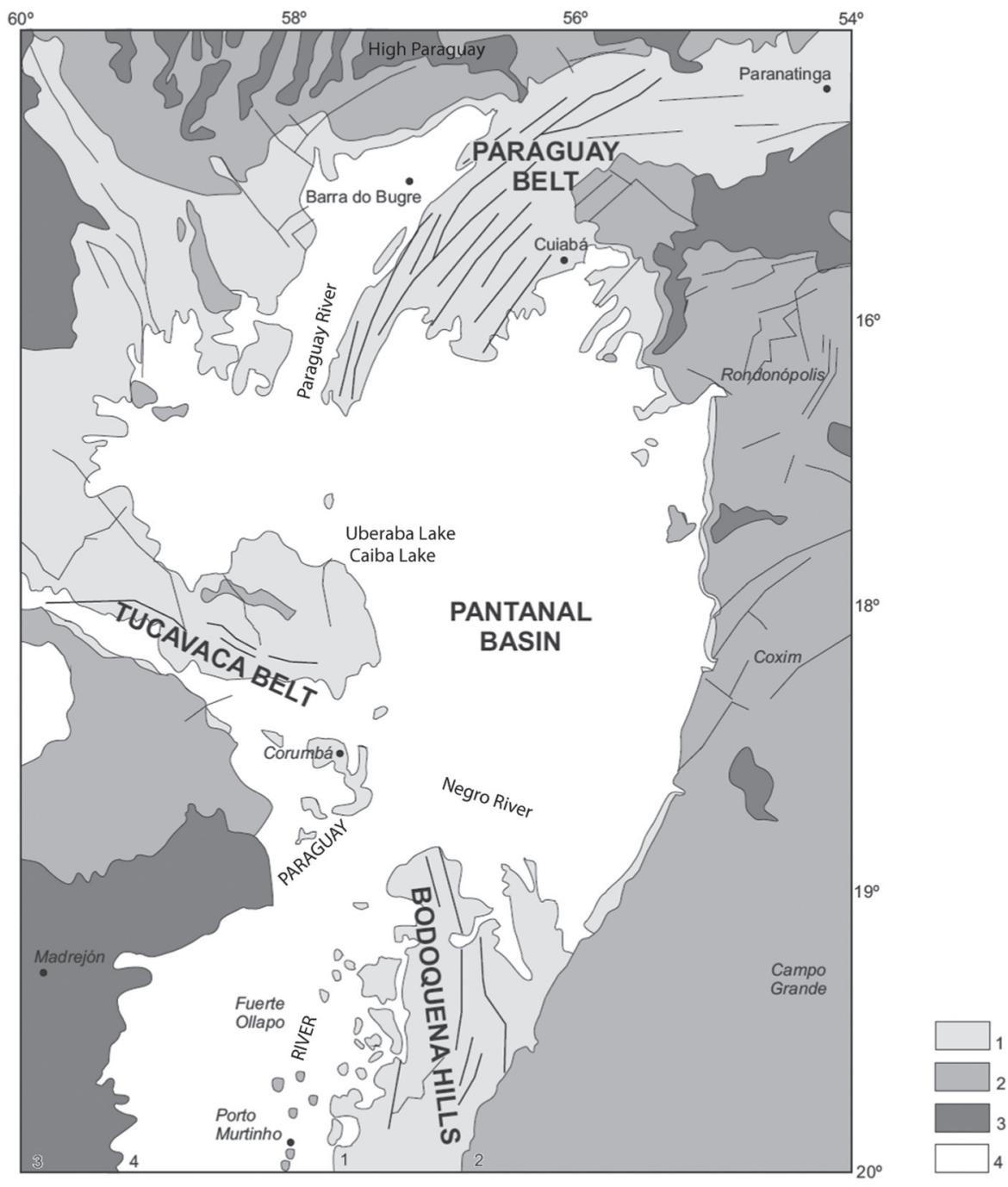

Figure 1 - The geological context of Pantanal in relation to regional tectonic units (simplified from Schobbenhaus and Bellizzia 2001): (1) Precambrian metamorphic rocks; (2) Gondwana sequence with Paleozoic sedimentary rocks; (3) Tertiary sedimentary rocks, and (4) Cenozoic sequences including Pantanal. It is important to observe the structural context with the metamorphic rocks of Paraguay Belt to the north; Bodoquena Hills to the south, composed by carbonates and other metamorphites; the Paraná Basin to the east, and Precambrian rocks of the Tucavaca Belt and Bolivian Cenozoic sediments to the west. 


\section{MATERIALS AND METHODS}

Over a false color composition of a CBERS-2B Satellite image, WFI sensor (Instituto Nacional de Pesquisas Espaciais (INPE), 2008a, b), the main lineaments were identified and vectorized on screen by means of the Quantum GIS Software (OSGeo 2011).

The Quantum GIS Project, supported by the Open Source Geospatial Foundation (OSGeo), is currently developing a user friendly Open Source Geographic Information System (GIS) licensed under the GNU General Public License. It is a free software and can be customized freely. It runs on several operating systems and supports numerous vector, raster, and database formats and functionalities.

The WFI (wide field imager) images, available for free download from the INPE website, have $260 \mathrm{~m}$ spatial resolution and two channels in the red and near infrared spectral regions. The third band used to create the false color composition is the NDVI (Normalized Difference Vegetation Index), derived from the red and infrared channels.

One interesting characteristic is that WFI sensor with its $890 \mathrm{~km}$ wide scanning range allows to view large portions of viewed land cover at once, allowing large portions of land cover to be viewed so that the whole Pantanal is sampled in only two scenes of the same date. Other sensors, like Landsat TM or ETM+, for example, would capture the same land area in at least 48 days. The resulting mosaic would show differences in the vegetation cover due the humidity and phenology, whereas this bias is negligible in the WFI images obtained on the same day.

The dry season, due to hydric stress, causes a decrease of chlorophyll in vegetation and consequent changes in the spectral response of the land cover in the satellite images. The rainy station also causes variations in the land cover, mainly through flood pulses. Images from rainy and dry seasons were compared in order to depict possible differences due to seasonality and define the correct location of the photointerpreted lineaments.

The images were used in compliance with PROBIO (official limits established by the Brazilian Ministry of Environment for the Pantanal, published in Silva and Abdon 1998) and also the official limits of the Upper Paraguay river hydrographic basin.

The Brazilian Geological Survey (CPRM - Schobbenhaus and Bellizzia 2001) has also geological maps for the Pantanal surrounding region focusing on prospecting, ruling out the Pantanal Basin, which is of Cenozoic age. However, the map of lineaments generated by CPRM for the surrounding area was used in the analysis of the photointerpreted structures. There are about a dozen CPRM maps of that cover the Cenozoic Plain of Pantanal (Figure 2).

Field control was carried out in two field trips, the first in July, 2011 and the second in August, 2011, in order to check the structural data compiled from the images. The southern and eastern borders of Pantanal were covered during these trips, totaling more than 300 ground control points.

During the field works the physiography of the terrain (breaklines) was analyzed and the directions of the rock bedding were obtained by means of the geological compass. The vectors of the structural lineaments were checked against a road map to avoid misinterpretations.

\section{RESULTS AND DISCUSSION}

The structures compiled by means of photointerpretation of the CBERS-2B satellite image are presented in Figure 3. Three main systems are distinguished:

- An almost NS, NNE/SSW-trending system that encompasses the eastern edge of the Pantanal Basin, coinciding with the western boundary of the Paraná Sedimentary Basin. This direction also controls the Paraguay River on the western borderline of the Pantanal Basin. 


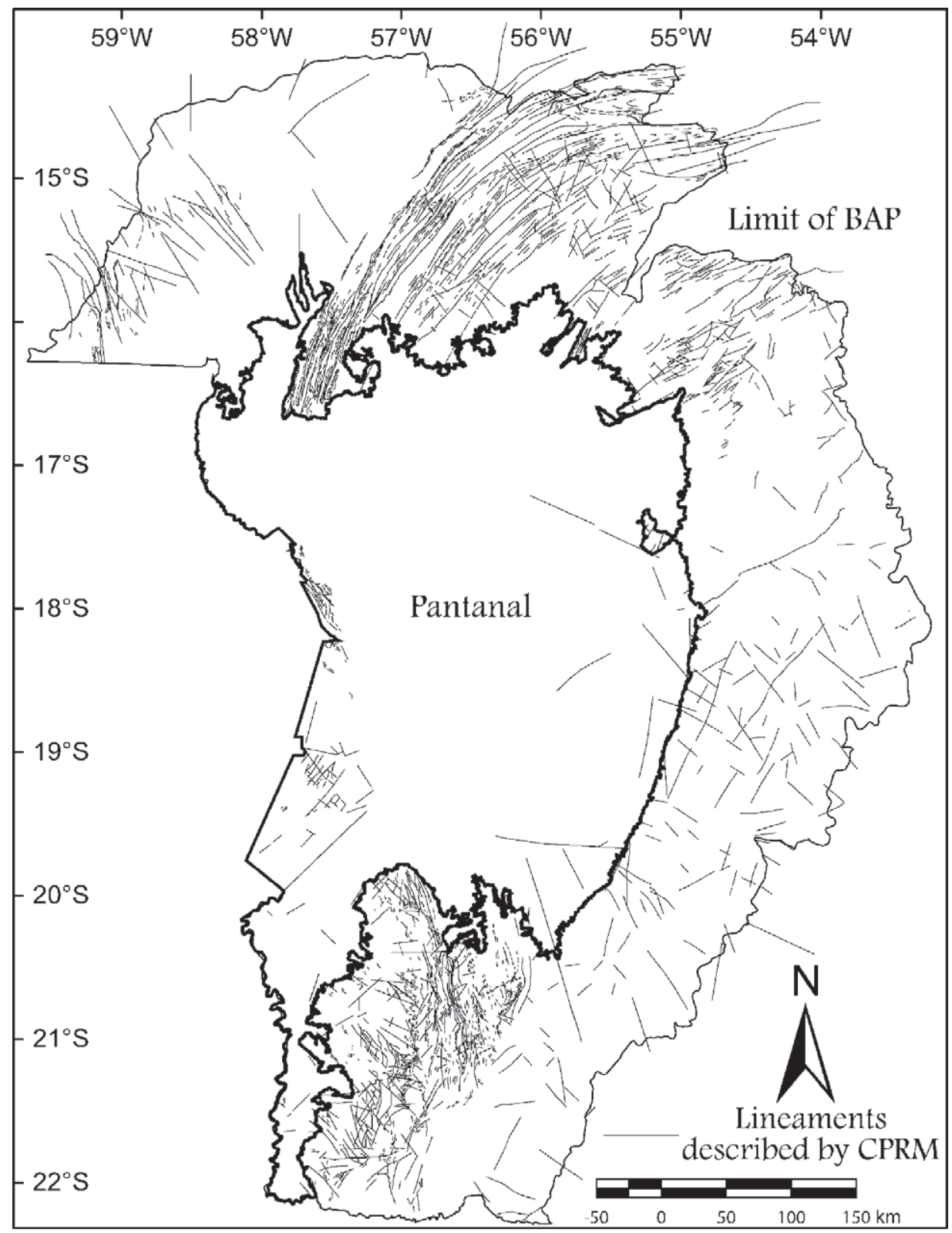

Figure 2 - Map of regional lineaments surrounding the Pantanal (structural data from CPRM - Schobbenhaus and Bellizzia 2001). The Upper Paraguay basin and Pantanal limits are from PROBIO (Silva and Abdon 1998).

- Two lineament systems, a main NE-SW and a secondary NW-SE compose the second system.

- The third system trending EW is situated on the southern edge of the Pantanal Basin, being well marked between the alignments of the Negro River and the Tucavaca lineament. It is also visible on the middle of Pantanal.
$\mathrm{NE}$ and NW lineaments are long (over $50 \mathrm{~km}$ ), continuous, and extremely straight, penetrating the Pantanal region and the adjacent regional tectonic units. Lineaments with these same directions, but with smaller length, occur on the eastern edge of the Pantanal Basin.

The lineaments following NS structures are also persistently continuous in the images. Nonetheless, 


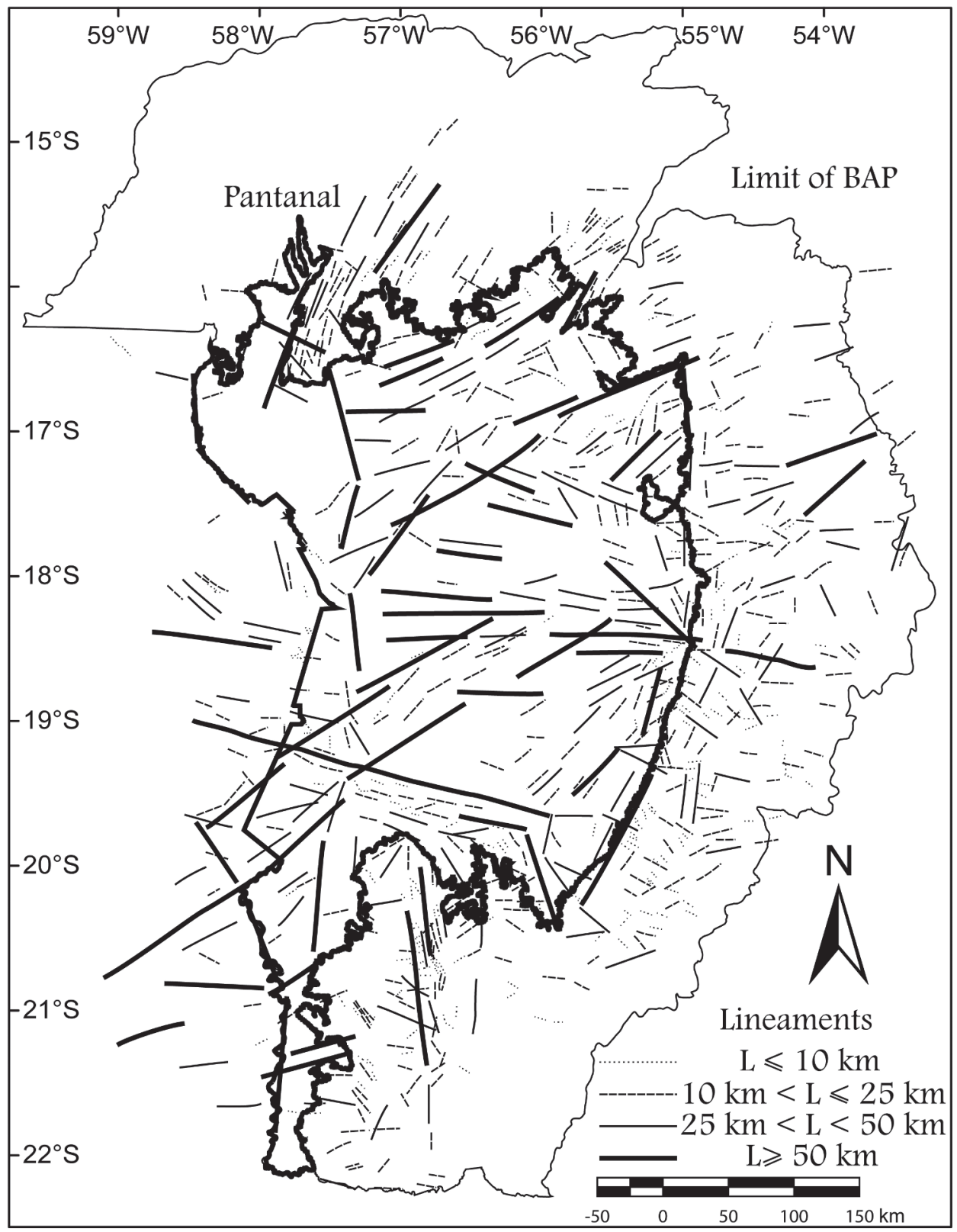

Figure 3 - The lineaments obtained through photointerpretation of satellite images. The main systems are NNE/SSW, EW, NE/SW and NW/SE (the last two being associated sub-systems).

they are more targeted and their trace is restricted to "corridors", as the eastern edge of the Pantanal Basin, where such structures are coincident with the edge of the Paraná Basin and with the outcrops of Precambrian rocks visited during the fieldtrips. The Paraguay River flows in a corridor with this orientation on the west border of Pantanal.
The largest EW lineaments, with length exceeding $50 \mathrm{~km}$, generally occur in the central part of the Pantanal.

The comparison between the data for the Pantanal Basin and the surrounding area, taking into account the correspondence with the direction and length of the lineaments, is shown in Figure 4. 
There is a good correlation between these diagrams for each area. There is a meaningful difference between the two areas. The directions in the area of the Pantanal Basin are concentrated around ENE and WNW, whereas there is a great dispersion of surrounding data in the rose diagrams, which show a main concentration around NE and another around NS.
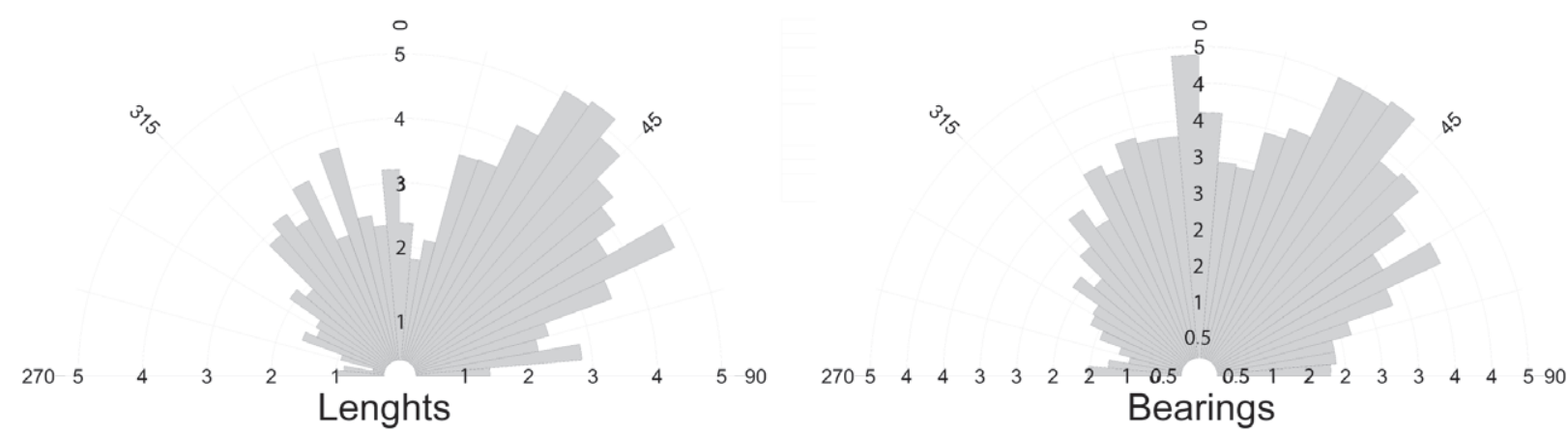

A: 2556 attitudes - CPRM charts - Upper Paraguay river basin (surrounding area; without the Pantanal basin area).

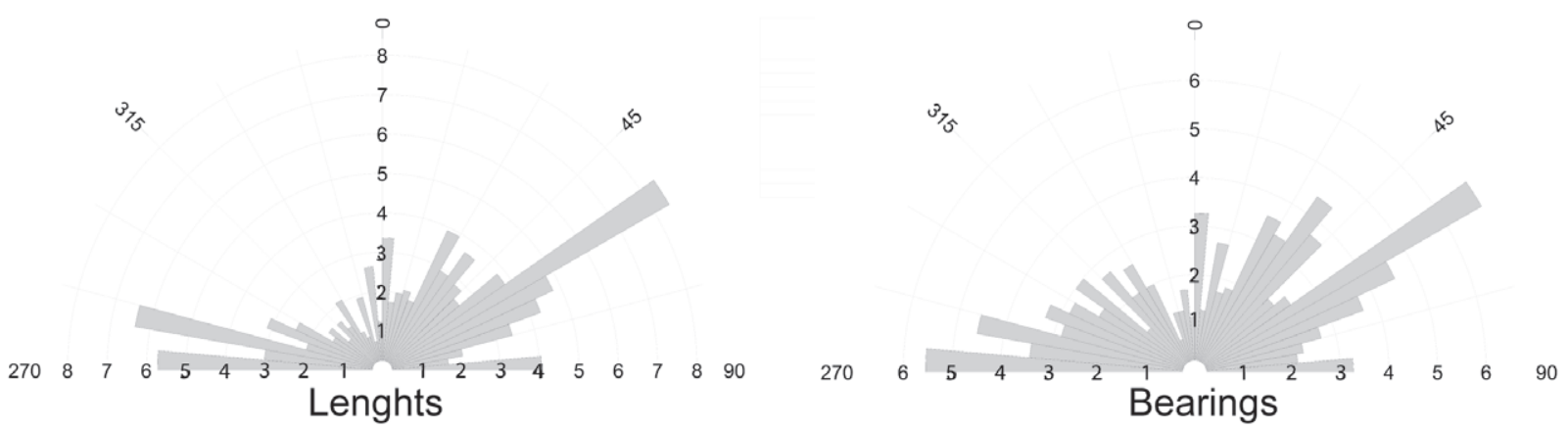

B: 704 attitudes - from satellite image photointerpretation - Upper Paraguay river basin.

Figure 4 - Rose diagrams with the lineaments from CPRM (A) and from the photointerpretation of the satellite image (B). No stronger trend is depicted in "A", except for a suggestion of NE and NS structures. The rose diagrams with length-proportional frequency show the importance of the NE direction, which is associated with the Transbrasiliano Lineament. There are two important systems marked on B: one trending ENE and the other trending almost EW.

The NNE/SSW lineaments found in this work could be associated with the initial phases of the opening of the Pantanal Basin before the Pleistocenic deposition, according to the model proposed by Almeida (1965) for the Pantanal Basin, corroborated by Ab'Saber $(1988,2006)$.

In the central region of Brazil the directions associated with the N45E directions according to Hasui (1990) may be associated with neotectonic activities and to the Transbrasiliano Lineament (Schobbenhaus et al. 1975), a Neoproterozoic brittle structure with reactivation phases in the Paleozoic, Mesozoic and Cenozoic. According to Soares et al. (1998), Assine and Soares (2004) and Facincani et al. (2011), these structures played a significant rule on the evolution of the Pantanal Basin.

These structures are visible not only in the Pantanal Basin, but also crossing its limits towards the Precambrian, Paleozoic and Mesozoic terrains arround the basin. This means that there has been reactivation of these structures in different geological periods. 
Riccomini (1989, 1995a, b) proposed a stress field with $\sigma 1$ oriented to EW during the Cenozoic. For some authors this same stress field persisted during the Quaternary and continued until the present time (Assumpção 1992, Lima and Nascimento 1994, Riccomini 1995a).
It is important to observe that the field control showed that the structures observed in the images match with positive and negative physiographic breaklines on the terrain (Figure 5)

The presence of structures with the magnitude of those found in the Pantanal Basin is associated

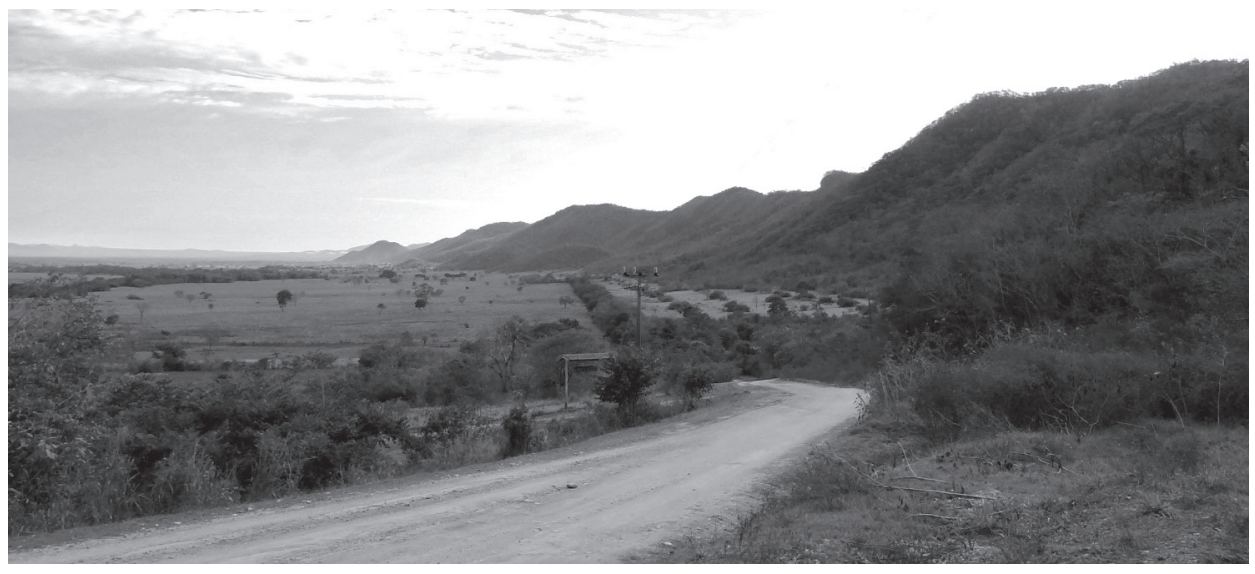

Figure 5 - A series of hills aligned according to the NS direction. The picture was taken from the Bodoquena Belt looking northwards.

with active tectonics or reactivation as this basin is filled with recent and immature sediments that can be easily remobilized by the basin fluvial systems, thus masking the structural system. Some sort of structural control must exist to keep these lineaments visible and controlling the drainage under an intense depositional regime.

\section{CONCLUSIONS}

The results of this study are similar to the data obtained by the Geological Survey of Brazil in the area surrounding the Pantanal Basin. They only differ in the smaller dispersion of the data and the concentration of the main lineament directions. In the area of the Pantanal, directions are concentrated around ENE and WNW, whereas in its surroundings they are concentrated around NE and NS.

The NE, NW and NS tectonic directions characterized in the Pantanal region have been reactivated since the late Pleistocene to the present day and they correspond to the general structural pattern present in basement rocks.
Special exception for EW structures, which are newer than the others, as well as the sedimentary sequence of the Pantanal Basin. Although many authors consider the NE structural directions of the Pantanal Basin to be related to the reactivation of the Transbrasiliano Lineament, the EW stress field produced in the South American Plate during the late Pleistocene to Quaternary may also be responsible for such reactivation.

The Pantanal corresponds to a tectonic basin elongated in the NS direction, whose evolution and tectono-sedimentary deformation are probably related to the Andean convergence, including the EW structures, younger than the stratigraphic succession of the Pantanal Basin. The structural directions NE, NW and EW are responsible for controlling the main rivers that currently drain the Pantanal plain.

Concerning the methodological aspects of this work, the application of a free software and free images is recommended for further environmental studies. 


\section{ACKNOWLEDGMENTS}

To Conselho Nacional de Desenvolvimento Científico e Tecnológico (CNPq) (process number 151762/2010-4) for ACPF Post-Doctor Senior scholarship and to Fundação de Amparo à Pesquisa do Estado de São Paulo (FAPESP) (process number 2010/52614-4) for supporting part of the field work.

\section{RESUMO}

Este trabalho apresenta um estudo dos lineamentos estruturais extraídos manualmente a partir de imagens de satélite (CBERS-2B, sensor WFI, uma imagem gratuita disponível na internet) da região do Pantanal e faz uma comparação com os lineamentos estruturais de rochas Pré-Cambrianas e Paleozóicas que circundam a bacia Cenozóica do Pantanal. Usando software livre para análise de imagens de satélite, a fotointerpretação mostrou que as direções NS, NE e NW observadas no Pantanal são as mesmas registradas nas rochas mais antigas que circundam a bacia, sugerindo reativação destas mesmas direções estruturais durante o Quaternário. Logo, a Bacia do Pantanal possui uma tectônica ativa e sua evolução parece estar ligada às mudanças relacionadas com a subducção Andina.

Palavras-chave: programa livre para sensoriamento remoto, imagem de satélite gratuita, geologia estrutural, lineamentos, fotointerpretação, Pantanal.

\section{REFERENCES}

AB'SABER A. 1988. O Pantanal Mato-Grossense e a Teoria dos Refúgios. Rev Bras Geogr 50 (número especial, cinquentenário) tomo 2: 9-57.

AB'SABER A. 2006. Brasil: Paisagens de Exceção. O litoral e o Pantanal Mato-Grossense. Patrimônios Básicos. Ateliê Editorial. Cotia, SP, 182 p.

ALMEIDA FFM. 1965. Geologia da Serra da Bodoquena (Mato Grosso). Boletim. Divisão de Geologia e Mineralogia, Rio de Janeiro: DNPM, n. 219, p. 7-96.

ALMEIDA FFM. 1967. Origem e evolução da Plataforma Brasileira. Boletim. Divisão de Geologia e Mineralogia. Rio de Janeiro: DNPM, n. 241, p. 1-36.

Assine ML. 2010. Pantanal Mato-Grossense: uma paisagem de exceção. In: Modenesi-Gauttieri MC, Bartorelli A, Mantesso-Neto, V, Carneiro CDR and Lisboa MBAL (Eds), A Obra de Aziz Nacib Ab'Saber. São Paulo, BecaBALL edições, p. 464-489.
ASSINE ML AND SOARES PC. 2004. Quaternary of the Pantanal, west-central Brazil. Quaternary International 114: 23-34.

ASSUMPÇÃO M. 1992. The regional interplate stress Field in South America. J Geophy Res 97(11): 889-903.

ASSUMPÇÃO M, FERNANDES CM AND FACINCANI EM. 2009b. O sismo do Pantanal de 15/06/2009 de magnitude 4,8. $11^{\circ}$ Congr. Bras. Geofísica, Salvador, SBGf.

ASSUMPÇÃo M, LOPER AEV, ZEVALLOS I, FERREIRA JM AND NASCIMENTO A. 2009a. Intraplate Stress Field in Brazil from Earthquake Focal Mechanisms. Conferencia Internacional en Homenaje a Alberto Giesecke, CERESIS, Lima, Peru.

ASSUMPÇÃO M AND SuÁREZ G. 1988. Source mechanisms of moderate size earthquakes and stress orientation in mid-plate South America. Geophys J 92: 253-267.

BRANNER JC. 1912. Earthquakes in Brazil. Bull Seismic Soc Am 2(2): 105-117.

FACINCANI EM, ASSUMPÇÃo MS, ASSINE ML AND FRANÇA GLSA. 2011. Sismicidade da Bacia do Pantanal MatoGrossense. In: Anais do XIII Simpósio Nacional de Estudos Tectônicos (XIII SNET). Campinas, SP 1: 314-317.

HASUI Y. 1990. Neotectônica aspectos fundamentais da tectônica ressurgente no Brasil. In: Worshop sobre a tectônica e sedimentação Cenozóica continental no sudeste brasileiro , 1. 1990, Belo Horizonte. Anais... Belo Horizonte: SBG-MG, p. 1-31. (Boletim 11).

HASUI Y. 2010. A grande colisão pré-cambriana do sudeste brasileiro e a estruturação regional. Universidade Estadual Paulista "Julio de Mesquita Filho". Geociências 29(2): 141-169.

INPE - Instituto NACiONAL DE Pesquisas Espaciais. IMAGEM DE SATÉlite. 2008a. CBERS 2B - Sensor WFI. Canais 1 e 2. São José dos Campos. Órbita 165 ponto 116. De 24 de Agosto de 2008 (a). Disponível em: http://www. dgi.inpe.br/CDSR/ . Last access on: feb, 8/2011.

INPE - InSTITUTO NACIONAL DE PESQUisas EsPaCiais. IMAGEM DE SATÉLITE. 2008b. CBERS 2B - Sensor WFI. Canais 1 e 2. São José dos Campos. Órbita 165 ponto 124. De 24 de Agosto de 2008 (b). Disponível em: http://www. dgi.inpe.br/CDSR/ . Last access on: feb, 8/2011.

LIMA CC AND NASCIMENTO E. 1994. Stress orientation in Brazilian sedimentary basins from breakout analysis: implications for force models in the South America plate. Geophys J Int 130(1): 112-124.

O'LEARY DW, FrEIDMAN JD AND POHN HA. 1976. Lineament, linear, lineation: Some proposed new definitions for old terms. Geol Soc Am Bull 87: 1463-1469.

OSGEO - Open Source Geospatial Foundation. 2011. Quantum GIS (QGIS). Open Source Geographic Information System (GIS). Version 1.6.0. "Copiapó". Avaliable at: http://qgis.org/.

Riccomini C. 1989. O Rift Continental do sudeste do Brasil. Ph.D. Thesis, Inst. Geociências, Universidade de São Paulo, Brasil, 256 p. (restricted circulation). 
RICCOMINI C. 1995a. Tectonismo Gerador e Deformador dos Depósitos Sedimentares Pós-Gondwânicos da Porção Centro-Oriental do Estado de São Paulo e Áreas Vizinhas. Tese de Livre-Docência, Universidade de São Paulo, Brasil, 100 p. (restricted circulation).

RicCOMINI C. 1995b. Padrão de fraturamento do Maciço Alcalino de Cananéia, Estado de São Paulo: relações com a tectônica Mesozóica-Cenozóica do sudeste do Brasil. Rev Bras Geoc 25(2): 79-84.

RICCOMINI C AND ASSUMPÇÃO M. 1999. Quaternary tectonics in Brazil. Episodes 22(3): 221-225.

Schobbenhaus C AND Bellizzia A (COORD). 2001. Mapa Geológico da América do Sul, 1:5.000.000, CGMW CPRM - DNPM - UNESCO, Brasília. CDROM.

SchobBenhaus C ET AL. 1975. Carta Geológica do Brasil ao milionésimo; folha Goiás (SD.22). Brasília: MME/DGM/ DNPM, $144 \mathrm{p}$
SILVA JSV AND ABDON MM. 1998. Delimitação do Pantanal Brasileiro e suas sub-regiões. Pesquisa agropecuária brasileira. Brasília, v. 33(out), Número Especial, p. 1703 1711.

Soares PC, Assine ML and Rabelo L. 1998. The Pantanal Basin: Recent Tectonics, Relationships to the Transbrasiliano Lineament In: SIMPÓSIO BRASILEIRO DE SENSORIAMENTO REMOTO, 9. (SBSR), 1998, Santos. Anais... São José dos Campos: INPE, p. 459469. CD-ROM. ISBN 85-17-00015-3. (INPE-6909PRE/2875). Disponível em: http://marte.dpi.inpe.br/col/ sid.inpe.br/deise/1999/02.08.10.23/doc/1 141o.pdf> Acesso em: 20 set. 2011.

ZANI H AND Assine ML. 2011. Paleocanais no megaleque do rio Taquari: mapeamento e significado geomorfológico. Rev Bras Geoc 41(1): 37-43. 